\title{
Canal Wall down Mastoidectomy and Tympanoplasty in Cholesteatoma Surgery: Ten Years' Experience
}

\author{
Salvatore Ferlito ${ }^{1}$, Eugenia Allegra², Calogero Grillo${ }^{1}$, Gian Luca Fadda ${ }^{3}$, Salvatore Conticello ${ }^{3}$ \\ ${ }^{1}$ Otolaryngology Clinic, University of Catania, Catania, Italy \\ ${ }^{2}$ Otolaryngology Clinic, University of Catanzaro, Catanzaro, Italy \\ ${ }^{3}$ Otolaryngology Clinic, University of Torino, Torino, Italy \\ Email: ferlito@unict.it, eualle@unicz.it,s.conticello@libero.it,glfadda@libero.it
}

How to cite this paper: Ferlito, S., Allegra, E., Grillo, C., Fadda, G.L. and Conticello, S. (2016) Canal Wall down Mastoidectomy and Tympanoplasty in Cholesteatoma Surgery: Ten Years' Experience. International Journal of Otolaryngology and Head \& Neck Surgery, 5, 195-202.

http://dx.doi.org/10.4236/ijohns.2016.55031

Received: September 1, 2016

Accepted: September 24, 2016

Published: September 27, 2016

Copyright $\odot 2016$ by authors and Scientific Research Publishing Inc. This work is licensed under the Creative Commons Attribution International License (CC BY 4.0).

http://creativecommons.org/licenses/by/4.0/

\begin{abstract}
Tympanomastoid surgery for cholesteatoma is a procedure designed to eliminate the disease and maintain a safe and dry ear. This retrospective study was designed to evaluate the functional results of cholesteatoma patients who underwent canal wall down mastoidectomy in conjunction with a tympanoplasty. Operated ears due to chronic otitis media with cholesteatoma were considered for the study. The study was carried out in 120 ears. The choice of technique for tympanoplasty is based on the pathology encountered in the stapes superstructure. Patients were divided into three: 1) Group A, a type II TPL with stapes columella reconstruction; 2) Group B, a type III TPL with major columella reconstruction; and 3) Group C, a type IV TPL using a temporalis fascia and thick cartilage to shield the round window. The operated ears of Groups A and B, as compared to Group C, presented a significant decrease in the pre-operative Air-bone gap and an increase in the number of operated ears with an Air-bone gap between $0-20 \mathrm{~dB}$. The study emphasizes the importance of functional separation of the two acoustic windows by fascia and cartilage graft when the stapes superstructure is missing but the footplate is mobile.
\end{abstract}

\section{Keywords}

Tympanomastoid Surgery, Cholesteatoma, Tympanoplasty

\section{Introduction}

Tympanomastoid surgery for cholesteatoma is a procedure, in decreasing order of priority, designed to (a) the elimination of disease to maintain a safe and dry ear, (b) 
the alteration of anatomy to prevent recurrent disease, and to optimize cleaning and otologic monitoring, and (c) the reconstruction of the middle ear to achieve serviceable and stable [1]. Various techniques for cholesteatoma surgery have been developed. Initially, the most diffused procedure was the canal wall up mastoidectomy (CWU-M) [2]-[4], nowadays, the canal wall down mastoidectomy (CWD-M) is performed [5] [6]. Previous studies have compared hearing results between ears in the CWU-M and in CWD-M for comparable ossicular pathology: there were no significant differences in hearing results whether the canal wall was intact or not [7]-[12]. The best hearing results occurred when the ossicular chain was intact and mobile [1] [13] [14]. When the ossicular chain was diseased, better results occurred if the stapes was intact [7] [13][15]. In CWD-M, stapes columella reconstructions were superior to major columella reconstructions by approximately $5 \mathrm{~dB}$ (0.05 at most frequencies) [16]. There was a large range of postoperative air-bone gaps ( 0 to $60 \mathrm{~dB})$ after tympanoplasty procedures. Factors responsible for persistent conductive hearing loss for tympanoplasty are multiple; some are the results of healing responses of the ear (e.g., fibrosis) and of continued biological abnormalities caused by chronic ear disease, while others are problem mechanisms of the TM (e.g., blunting), problems with mechanics of ossicles grafts, and negative static pressure in the middle ear [17] [18]. In conducting this study, a CWD-M and tympanoplasty (TPL) are routinely combined when treating ears with cholesteatoma. The type of reconstruction depends on the condition of the ossicular chain: a) when the stapes is fixed, the procedure in tympanoplasty is staged; b) when the ossicles are mobile, it is preferred to combine elimination of disease and reconstruction of hearing in one stage. The present team uses the following classification of tympanoplasty: type 1, in cases with an intact ossicular chain at the end of the operation; type 2, ossiculoplasty in cases with a defective ossicular chain, but with the stapes present; type 3 , ossiculoplasty in cases with an absent, or severely defective, stapedial arch. If columella techniques are used, the columella goes from the footplate to the malleus handle or the grafted eardrum; type 4, it does not involve ossiculoplasty as such, but is protection mechanism for the round window in cases with absent ossicles, but with an intact and mobile footplate, type 4 technique also includes the cavum minor technique or sound-protection techniques; type 5 , this means platinectomy in cases with a fixed footplate and no ossicles. This retrospective study was designed to evaluate the functional results of cholesteatoma patients who underwent CWD-M in conjunction with a tympanoplasty.

\section{Material and Methods}

\subsection{Patients}

Operated ears due to chronic otitis media with cholesteatoma in the period from January 2000 to December 2010 were considered for the study. The inclusion criteria for these studies were: (a) clinical and histological diagnosis of cholesteatoma, (b) no previous otologic surgery, (c) one-stage CWD-M and TPL (d) two years follow-up; and (e) middle ear was judged to be aerated postoperatively by otomicroscopy. Non-aerated 
ears caused by middle ear fibrosis, graft atelectasis, or tubal dysfunction show large 40 to $60 \mathrm{~dB}$ conductive hearing losses, regardless of the type of tympanoplasty [17] [19]. Removing the confounding variable of non-aeration in the analysis of postoperative hearing permits a more meaningful comparison of results among different techniques. Functional results were evaluated two years after surgery according to the guidelines of the "Committee on Hearing and Balance" of AAO-HNS (American Academy of Otolaryngology Head and Neck Surgery) [20]. Pure tone average (PTA) was calculated as the mean of 0.5, 1, 2 and $3 \mathrm{kHz}$. The $3 \mathrm{kHz}$ threshold was obtained from the average of the frequencies 2 and $4 \mathrm{kHz}$. Air-bone gap (ABG) was calculated by air and bone conduction that determined the threshold in each study. Post-operative hearing gain was calculated from the PTA before the operation and the last follow-up examination. All data of the patients included in the study, were collected in a database. All patients gave their informed consent. None of the authors have any conflict of interest.

\subsection{Surgical Technique}

A complete CWD-M with meatoplasty and canaloplasty is performed with a postauricolar approach, through exenteration of all mastoid air cells, along with lowering of the facial ridge to the level of the facial nerve and obliteration of the mastoid with bone pate and a periosteal-pericranial flaps. The choice of technique for tympanoplasty is based on the pathology encountered in the stapes superstructure (Table 1): Group A, when the stapes superstructure is intact with a mobile footplate, a type II TPL with stapes columella reconstruction is performed by placing a only temporalis fascia graft or a thin cartilage disk and a temporalis fascia graft are placed directly on stapes head (or capitellum); Group B, when the stapes superstructure is missing but the footplate is mobile, a type III TPL with major columella reconstruction is performed: a total ossicular replacement prosthesis (TORP) or a transposed incus is placed from stapes footplate to the tympanic membrane; a thin slice of cartilage is introduced between the TORP and the fascia graft; Group C, when the stapes superstructure is missing but the footplate is mobile, a type IV TPL is performed using a temporalis fascia and thick car-

Table 1. Performed technique for TPL.

\begin{tabular}{|c|c|c|c|}
\hline Group & Type of Tympanoplasty & Ossicular pathology & Grafts \\
\hline \multirow{4}{*}{ A } & \multirow{4}{*}{ Type II-stapes columella } & & TF graft alone \\
\hline & & Stapes intact and & or \\
\hline & & Mobile footplate & thin cartilage disk and TF \\
\hline & & & over stapes head \\
\hline \multirow{4}{*}{$\mathrm{B}$} & & Stapes superstructure missing & \multirow{4}{*}{$\begin{array}{c}\text { TORP+thin cartilage }+\mathrm{TF} \\
\text { or } \\
\text { trasposed incus+TF }\end{array}$} \\
\hline & & and footplate mobile: & \\
\hline & & & \\
\hline & Type III-major columella & - OW niche deep and narrow & \\
\hline $\mathrm{C}$ & Type IV-round window & - OW niche shallow and wide & $\begin{array}{c}\text { TF over footplate and thick } \\
\text { cartilage to shield RW }\end{array}$ \\
\hline
\end{tabular}

Abbreviations: OW, Oval window; TF, temporalis fascia; RW, round window. 
tilage to shield the round window. A type IV reconstruction is preferred when the oval window niche is shallow and wide; while the TORP technique is better suited for a deep and narrow oval window niche, which makes it problematic for fascia graft to adhere to the footplate. The principle of a type IV is to exteriorize the footplate. Other authors cover it with a very thin split thickness skin graft; acoustically separate the oval window from the round window, and to shield the round window with a sufficiently stiff tissue graft. Covering the footplate with a fascia graft instead of a skin graft carriers the risk of healing by fibrosis, resulting to the impairment of mobility of the footplate [17] [19].

To reconstruct the tympanic membrane, the preferred graft material is temporalis fascia. To reconstruct the ossicular chain and restore the transmission of sound was used both the synthetic (titanium) and remodeled and transposed incus. Incus is the first material chosen in ossiculoplasty, however, it is not always usable [21]. All patients were treated by the same team.

\subsection{Statistical Analysis}

Statistical analysis of the results was performed, using MedCalc software, with the Anova-test and chi-square test. The test was significant with $\mathrm{p}<0.05$.

\section{Results}

A total of 396 ears were operated, and considering the criteria, 178 ears with incomplete clinical history submitted to radical mastoidectomy or staged Timpanoplasty (open or closed) were excluded. In addition, 98 ears were also excluded because they had not followed up for two years or has no aerated ear. The study was carried out only in 120 ears. Of the 120 ears, 69 were males and 51 are females. The mean age at surgery was 47.36 years (range 8 - 70), mean time interval from surgery to postoperative audiogram was 36 months. Functional results of the three groups of cholesteatoma patients who underwent CW-M and TPL have been compared (Table 2). Group A (CWD-M and Type II TPL with stapes columella) consisted of 65 ears from 41 males and 24 females, mean age 42.6 years (range: 8 - 55). In this group, the temporalis fascia graft was placed directly on the stapes in 48 ears, whereas a thin cartilage-fascia graft was placed over stapes head in 17 ears. Group B (CWD-M and Type III TPL with major columella) consisted of 42 ears from 20 males and 22 females, mean age 44.8 years (range: 16 - 67).

Table 2. Clinical date.

\begin{tabular}{|c|c|c|c|c|c|c|c|}
\hline Group & $\begin{array}{c}\text { Type of } \\
\text { Tympanoplasty }\end{array}$ & $\begin{array}{l}\text { No. of } \\
\text { ears }\end{array}$ & $\mathrm{M} / \mathrm{F}$ & $\begin{array}{c}\text { Age mean } \\
\text { (years) } \\
\text { (range) }\end{array}$ & $\begin{array}{c}\text { Pre-operative } \\
\text { ABG mean }(\mathrm{dB}) \\
\text { (range) }\end{array}$ & $\begin{array}{l}\text { Post-operative } \\
\text { ABG mean }(\mathrm{dB}) \\
\quad(\text { range })\end{array}$ & $\begin{array}{l}\text { ABG Gain } \\
\text { mean }(d B)\end{array}$ \\
\hline A & $\begin{array}{l}\text { Type II-stapes } \\
\text { columella }\end{array}$ & 65 & $41 / 24$ & $\begin{array}{c}42.6 \\
(8-55)\end{array}$ & $\begin{array}{c}26.43 \\
(5-40)\end{array}$ & $\begin{array}{c}23.70 \\
(5-40)\end{array}$ & +2.73 \\
\hline B & $\begin{array}{l}\text { Tipo III-major } \\
\text { columella }\end{array}$ & 42 & $20 / 22$ & $\begin{array}{c}44.8 \\
(16-67)\end{array}$ & $\begin{array}{c}29.16 \\
(15-60)\end{array}$ & $\begin{array}{c}30.01 \\
(15-55)\end{array}$ & -0.94 \\
\hline $\mathrm{C}$ & $\begin{array}{l}\text { Type IV-round } \\
\text { window }\end{array}$ & 13 & $8 / 5$ & $\begin{array}{c}54.7 \\
(20-70)\end{array}$ & $\begin{array}{c}28.81 \\
(20-60)\end{array}$ & $\begin{array}{c}25.20 \\
(20-35)\end{array}$ & +3.61 \\
\hline
\end{tabular}

Note: Average pre and post operative air-bone gaps in $\mathrm{dB}$ at $0.5,1,2$, and, $4 \mathrm{KHz}$. 
In this group a TORP and thin cartilage-fascia graft was placed in 32 ears and a transposed incus was placed in 10 ears. Group C (CWD-M and Type IV TPL) consisted of 13 ears from 8 males and 5 females, mean age 54.7 years (range: 20 - 70). In this group a temporalis fascia alone was placed in 8 ears and a thin cartilage-fascia graft to shield of the round window was placed 5 ears. The mean pre-operative of the ABG was $26.43 \mathrm{~dB}$ (range: $5-40 \mathrm{~dB}$ ) in Group A, $29.16 \mathrm{~dB}$ (range: $15-60 \mathrm{~dB}$ ) in Group B, and $28.81 \mathrm{~dB}$ (range: $20-60 \mathrm{~dB}$ ) in Group C. Two years after surgery, the average of ABG was 23.70 $\mathrm{dB}$ in Group A, $30.10 \mathrm{~dB}$ in Group B, and $25.20 \mathrm{~dB}$ in Group C. The mean post-operative of the ABG in the Group A patients submitted to type II TPL with temporalis fascia graft placed directly on the stapes was $25.1 \mathrm{~dB}$ while in those with cartilage-fascia graft placed over stapes was $22.3 \mathrm{~dB}$. This difference was not statistically significant ( $\mathrm{p}<$ 0.05). The average ABG improved by $2.37 \mathrm{~dB}$ in Group A, $3.61 \mathrm{~dB}$ in Group C but decreased to $-0.94 \mathrm{~dB}$ in Group B. The statistical analysis showed that two years after the surgery, the three groups differed in relation to the air and bone conduction. The difference between the three groups was significant $(\mathrm{p}=0.03)$.

Table 3 shows the numbers of ears with the average of the air-bone gap located within $0-20 \mathrm{~dB}, 25-40 \mathrm{~dB}$ and over $40 \mathrm{~dB}$ HL before and after the intervention in the three groups. The number of ears with $A B G$ between $0-20 \mathrm{~dB}$ is improved after surgery in all three groups. The number of ears with ABG located within $25-40 \mathrm{~dB} H \mathrm{HL}$ is improved after surgery in Group C. The number of ears with ABG over $40 \mathrm{~dB}$ HL decreased after surgery in Group C, it remained unchanged in the Group A, while it improved in Group B. In Group A, 48 ears with only a fascia graft, the ABG was closed to within $20 \mathrm{~dB}$ in 33 ears (50.76\%), within $21-40 \mathrm{~dB}$ in 28 ears (43.07\%), and over $40 \mathrm{~dB}$ in 4 ears $(6.17 \%)$. The improvement observed in the cartilage-fascia group over the fascia alone group was significant $(\mathrm{p}<0.05)$. The literature reveals that the cartilage disk increased the effective vibrating area of the tympanic membrane graft that was coupled to the stapes head [22]. In Group B, the ABG was closed to within $20 \mathrm{~dB}$ in 18 ears (42.85\%), within $21-40 \mathrm{~dB}$ in 15 ears (35.71\%), and over $40 \mathrm{~dB}$ in nine ears $(21.42 \%)$. The ears with ABG within $20 \mathrm{~dB}$ were increased, but the overall results of improvement observed were lower than to results after type II stapes columella. In Group C, the

Table 3. The number and percentage of ears with the average preoperative of the ABG and the average postoperative ABG located within $0-20 \mathrm{~dB}, 21-40 \mathrm{~dB}$ and over $40 \mathrm{~dB}$.

\begin{tabular}{|c|c|c|c|c|c|c|c|}
\hline \multirow{2}{*}{$\begin{array}{l}\text { Group } \\
\text { (No.) }\end{array}$} & \multirow{2}{*}{$\begin{array}{c}\text { Type of } \\
\text { Tympanoplasty }\end{array}$} & \multicolumn{2}{|c|}{$\begin{array}{c}\text { No. of ears } \\
\text { ABG } 0-20 \mathrm{~dB}\end{array}$} & \multicolumn{2}{|c|}{$\begin{array}{c}\text { No. of ears } \\
\text { ABG } 20-40 \mathrm{~dB}\end{array}$} & \multicolumn{2}{|c|}{$\begin{array}{c}\text { No. of ears } \\
\mathrm{ABG}>40 \mathrm{~dB}\end{array}$} \\
\hline & & Pre-op. & Post-op. & Pre-op. & Post-op. & Pre-op. & Post-op. \\
\hline $\begin{array}{c}\text { A } \\
(65)\end{array}$ & $\begin{array}{l}\text { Type II-stapes } \\
\text { columella }\end{array}$ & $\begin{array}{c}25 \\
(38.4 \%)\end{array}$ & $\begin{array}{c}33 \\
(50.7 \%)\end{array}$ & $\begin{array}{c}35 \\
(53.8 \%)\end{array}$ & $\begin{array}{c}28 \\
(43.07 \%)\end{array}$ & $\begin{array}{c}5 \\
(7.6 \%)\end{array}$ & $\begin{array}{c}4 \\
(6.15 \%)\end{array}$ \\
\hline $\begin{array}{c}\text { B } \\
(42)\end{array}$ & $\begin{array}{l}\text { Type III-major } \\
\text { columella }\end{array}$ & $\begin{array}{c}7 \\
(16.6 \%)\end{array}$ & $\begin{array}{c}18 \\
(42.8 \%)\end{array}$ & $\begin{array}{c}27 \\
(64.28 \%)\end{array}$ & $\begin{array}{c}15 \\
(35.7 \%)\end{array}$ & $\begin{array}{c}8 \\
(19.0 \%)\end{array}$ & $\begin{array}{c}9 \\
(21.5 \%)\end{array}$ \\
\hline $\begin{array}{c}\text { C } \\
(13)\end{array}$ & $\begin{array}{c}\text { Type IV_round } \\
\text { window }\end{array}$ & $\begin{array}{c}0 \\
(0.0 \%)\end{array}$ & $\begin{array}{c}5 \\
(38.5 \%)\end{array}$ & $\begin{array}{c}4 \\
(30.8 \%)\end{array}$ & $\begin{array}{c}6 \\
(46.2 \%)\end{array}$ & $\begin{array}{c}9 \\
(69.2 \%)\end{array}$ & $\begin{array}{c}2 \\
(15.3 \%)\end{array}$ \\
\hline
\end{tabular}

Note. Average post operative air-bone gap at $0.5,1,2$ and, $4 \mathrm{kHz}$. 
ABG was closed to within $20 \mathrm{~dB}$ in five ears (38.46\%), within $21-40 \mathrm{~dB}$ in 6 ears (46.15\%), and over $40 \mathrm{~dB}$ in 2 ears (15.38\%). The ears with ABG within $40 \mathrm{~dB}$ were $84.61 \%$. This result was lower than the Group A (98.83\%) but higher than the Group B (78.56\%). The differences between the results of the Group A and Group B were statistically significant as well as the differences between Group B and Group C; although the results of the Group C appear to be better than those of the Group B, the differences were not statistically significant $(\mathrm{P}>0.05)$. Comparing the results of Group A with those of the Group $\mathrm{C}$ was not statistically significant for the discrepancy of numbers in two groups.

\section{Discussion}

A review of the literature reveals few papers have reported results of hearing in CWD-M [23]-[26]. In the current study, the hearing results of patients with cholesteatoma undergoing CWD-M and (a) type II TPL-stapes columella (with a fascia or a cartilage-fascia graft), (b) type III TPL-major columella (with TORP or transposed incus), and (c) type IV TPL (with a fascia or a cartilage-fascia graft) were compared. In this study, the operated ears of Groups A and B compared to Group C presented a significant decrease in the pre-operative $A B G$, and an increase in the number of operated ears with an ABG between $0-20 \mathrm{~dB}$. The number of ears with a post-operative ABG 0 $20 \mathrm{~dB}$ ranges was between $38 \%$ and $50 \%$. In the different series [27]-[29], similar results (a mean post-operative $=17.8 \mathrm{~dB}$ [28] and $25.4 \mathrm{~dB}$ [22]) were obtained. Average postoperative $A B G$ was $26.43 \mathrm{~dB}$ in Group $A$ and $50.76 \%$ of patients had a post-operative ABG between 0 and $20 \mathrm{~dB}$. In Group A, the presence of the superstructure of the stapes is associated with better hearing results both pre-and post-operation. However, patients with type IV were few, this is a limitation of the study. The best results obtained in the operated ears of Group A and Group C, compared to those of Group B, when the ABG was more than $40 \mathrm{~dB}$, are related to poor gain obtained when ossiculoplasty (TORP) has not been functionally useful and, consequently, the difficulty of maintaining the pre-heard operating. While considering the abovementioned results, the results of this study should be compared with caution with those of other studies because of methodological differences in the analysis. The functional results confirm that the presence of an intact stapes superstructure is associated with better hearing results, both pre-and post-operative, a fact that has been noted in many previous studies [1] [7] [13]-[15], unlike what supported by other studies [30]. Moreover, the study emphasizes the importance of functional separation of the two acoustic windows by fascia and cartilage graft when the stapes superstructure is missing but the footplate is mobile.

\section{References}

[1] Nadol, J.B. and Schuknecht, H.F. (1993) Surgery of the Ear and Temporal Bone. 1th Edition, Raven Press, New York.

[2] Myers, D. and Schlosser, W.D. (1960) Anterior-Posterior Technique for the Treatment of Chronic Otitis Media and Mastoiditis. Laryngoscope, 70, 78-83. http://dx.doi.org/10.1288/00005537-196001000-00011 
[3] Sheehy, J.L. and Patterson, M.E. (1976) Intact Canal Wall Tympanoplasty with Mastoidectomy. A Review of Eight Years' Experience. Laryngoscope, 77, 1502-1542. http://dx.doi.org/10.1288/00005537-196708000-00018

[4] Zini, C., Sheehy, J.L. and Sanna, M. (1993) Microsurgery of Cholesteatoma of Middle Ear. Ghedini Editor, Milan.

[5] Palva, T., Karma, P. and Palva, A. (1977) Cholesteatoma Surgery: Canal Wall down and Mastoid Obliteration. In: McCabe, B., Sade, J. and Abramson, M., Eds., Cholesteatoma. First International Conference, Aesculapius, Birmingham, Alabama, 363-367.

[6] Smyth, G.D.L. and Hassard, T.H. (1981) The Evolution of Policies in the Surgical Treatment of Acquired Cholesteatoma of the Tubotympanic Cleft. The Journal of Laryngology \& Otology, 95, 767-773. http://dx.doi.org/10.1017/S0022215100091416

[7] Brackmann, D.E., Sheehy, J.L. and Luxford, W.M. (1984) TORPS and PORPS in Tympanoplasty: Review of 1042 Operations. Otolaryngology-Head and Neck Surgery, 92, 32-37.

[8] Colletti, V., Fiorino, F.G. and Sittoni, V. (1987) Minisculptured Ossicles Grafts versus Implants: Long-Term Results. American Journal of Otolaryngology, 8, 553-559.

[9] Toner, J.G. and Smyth, G.D.L. (1990) Surgical Treatment of Cholesteatoma: A Comparison of Three Techniques. American Journal of Otolaryngology, 11, 247-249.

[10] Roden, D., Honrubia, V.F. and Wiet, R. (1996) Outcome of Residual Cholesteatoma and Hearing in Mastoid Surgery. Journal of Otolaryngology, 25, 178-181.

[11] Whittemore, K.R., Merchant, S.N. and Rosowski, J.J. (1998) Acoustic Mechanisms: Canal Wall-Up versus Canal Wall down Mastoidectomy. Otolaryngology-Head and Neck Surgery, 118, 751-762. http://dx.doi.org/10.1016/S0194-5998(98)70264-5

[12] Gyo, K., Goode, R.L. and Miller, C. (1986) Effect of Middle-Ear Modification on Umbo Vibration-Human Temporal Bone Experiments with A New Vibration Measuring System. JAMA Otolaryngology-Head \& Neck Surgery, 112, 1262-1268. http://dx.doi.org/10.1001/archotol.1986.03780120026004

[13] Wullstein, H. (1960) Results of Tympanoplasty. Archives of Otolaryngology, 71, 478-485. http://dx.doi.org/10.1001/archotol.1960.03770030120024

[14] Lee, K. and Schuknecht, H.F. (1971) Results of Tympanoplasty and Mastoidectomy at the Massachusetts Eye and Ear Infirmary. Laryngoscope, 81, 529-543. http://dx.doi.org/10.1288/00005537-197104000-00004

[15] Jackson, C.G., Glasscock, M.E., Schwaber, M.K., et al. (1983) Ossicular Chain Reconstruction: The TORP and the PORP in Chronic Ear Disease. Laryngoscope, 93, 981-988. http://dx.doi.org/10.1288/00005537-198308000-00001

[16] Merchant, S.N., Rosowski, J.J. and McKenna, M.J. (2003) Operative Techniques. Otolaryngology Head and Neck Surgery, 14, 224-236. http://dx.doi.org/10.1053/S1043-1810(03)00092-7

[17] Merchant, S.N., Ravicz, M.E., Voss, S.E., Peake, W.T. and Rosowski, J.J. (1998) Middle-Ear Mechanism in Normal, Diseased and Reconstructed Ears. Journal of Laryngology and Otology, 112, 715-731. http://dx.doi.org/10.1017/S0022215100141568

[18] Merchant, S.N., McKenna, M.J., Meht, R.P., Ravicz, M. and Rosowski, J.J. (2003) Middle-Ear Mechanics of Type III Tympanoplasty (Stapes Columella): II. Clinical Studies. Otology \& Neurotology, 24, 186-194. http://dx.doi.org/10.1097/00129492-200303000-00010

[19] Merchant, S.N. and Rosowski, J.J. (2003) Auditory Physiology and Middle-Ear Mechanics. In: Glasscock, M.E. and Gulya, A.J., Eds., Surgery of the Ear, 5th Edition, BC Decker, Ontario, 59-82. 
[20] Committee on Conservation of Hearing of the American Academy of Opthalmology: Standard Classification for Surgery of Chronic Ear Infection (1964) Archives of Otolaryngology-Head \& Neck Surgery, 81, 204.

[21] Gandolfi, G., Ferlito, S., Fadda, G., Aversa, S. and Conticello, S. (2004) Timpanoplastica Aperta Nelle OMC Colesteatomatose Nell'Infanzia: Mastoidectomia Allargata o Quanto Più Limitata? Il Valsalva, 80, 61-66.

[22] Mehta, R.P., Ravicz, M.E., Rosowski, J.J. and Merchant, S.N. (2003) Middle Ear Mechanics of Type III Tympanoplasty (Stapes Columella): I. Experimental Studies. Otology \& Neurotology, 24, 176-185. http://dx.doi.org/10.1097/00129492-200303000-00009

[23] Amendola, S., Falcioni, M., Caylan, R. and Sanna, M. (1997) Recurrent Cholesteatoma in Open vs Closed Technique Tympanoplasties and Its Surgical Management. In: Sanna, M., Ed., Cholesteatoma and Mastoid Surgery, CIC Ed Internazionali, Roma, 654-659.

[24] Babighian, G. (2002) Posterior and Attic Wall Osteoplasty: Hearing Results and Recurrence Rates in Cholesteatoma. Otology \& Neurotology, 23, 14-17. http://dx.doi.org/10.1097/00129492-200201000-00004

[25] Vartiainen, E. and Nuutinen, J. (1992) Long Term Hearing Results of One Stage Tympanoplasty for Chronic Otitis Media. European Archives of Otorhinolaryngology, 249, 329331. http://dx.doi.org/10.1007/BF00179383

[26] Wang, Y.F., Lien, C.F., Wang, C.P. and Fu, C.Y. (2000) Type III Tympanoplasty with Cartilage Obliteration for Cholesteatoma Surgery. National Medical Journal of China, 63, 898903.

[27] Cook, J.A., Krishnan, S. and Fagan, P.A. (1996) Hearing Results Following Modified Radical versus Canal-Up Mastoidectomy. Annals of Otology, Rhinology \& Laryngology, 105, 379383. http://dx.doi.org/10.1177/000348949610500510

[28] Berenholz, L.P., Rizer, F.M., Burkey, J.M., Schuring, A.G. and Lipp, W.H. (2000) Ossiculoplasty in Canal Wall down Mastoidectomy. Otolaryngology_Head and Neck Surgery, 123, 30-33. http://dx.doi.org/10.1067/mhn.2000.106404

[29] Chang, C. and Chen, M. (2000) Canal-Wall down Tympanoplasty with Mastoidectomy for Advanced Cholesteatoma. Journal of Otology, 29, 271-273.

[30] Artuso, A., Di Nardo, W., De Corso, E., Marchese, M.R. and Quaranta, N. (2004) Canal-Wall-Down Tympanoplasty Surgery with or without Ossiculoplasty in Cholesteatoma: Hearing Results. Acta Otorhinolaryngologica Italica, 24, 2-3. 
Submit or recommend next manuscript to SCIRP and we will provide best service for you:

Accepting pre-submission inquiries through Email, Facebook, LinkedIn, Twitter, etc. A wide selection of journals (inclusive of 9 subjects, more than 200 journals)

Providing 24-hour high-quality service

User-friendly online submission system

Fair and swift peer-review system

Efficient typesetting and proofreading procedure

Display of the result of downloads and visits, as well as the number of cited articles

Maximum dissemination of your research work

Submit your manuscript at: http://papersubmission.scirp.org/

Or contact ijohns@scirp.org 